\title{
Effects of Tarragon Hydroalcoholic Extract and Coumarin On Memory, Tissue Index and GABAA Receptor Gene Expression in The Hippocampus of Male Rats
}

Nasrin Heidarieh ( $\square$ nas.heidarieh@gmail.com )

Islamic Azad University

Maryam Najafifard

Islamic Azad University

Ali Haeri Rohani

Islamic Azad University

Akram Eidi

Islamic Azad University

\section{Research Article}

Keywords: memory retention, GABAA gene expression, hippocampus, tarragon hydroalcoholic extracts, Coumarin, male rats.

Posted Date: September 9th, 2021

DOI: https://doi.org/10.21203/rs.3.rs-845467/v1

License: (c) (i) This work is licensed under a Creative Commons Attribution 4.0 International License.

Read Full License 


\section{Abstract}

\section{Background and objective:}

Learning and memory are necessary for survival. The hippocampus plays a significant role in learning process. GABAA receptors in the hippocampus are effective in learning and memory mechanism. The present study effect of tarragon hydroalcoholic extract and coumarin on memory, tissue index and GABAA receptor gene expression in the hippocampus of male rats.

\section{Methodology:}

56 Wistar rats were used and randomized in 7 groups $(\mathrm{N}=8)$. These groups included the intact, receiving DMSO, receiving tarragon hydroalcoholic extract doses of 25,50 and $100 \mathrm{mg} / \mathrm{kg}$ and receiving coumarin dose of $3,5 \mathrm{mg} / \mathrm{kg}$. They have undergone treatment intraperitoneally once a day for two weeks. The shuttle box was used for the memory retention test. The rats were killed according to the research ethical codes after the tests were done. When the brains of rats were removed, 4 brains in each group were chosen for the histological test using Nissl staining. In the other four brains, the hippocampus was removed immediately. The hippocampus was located in a microtube and was frozen by liquid nitrogen. Finally, a gene expression test was performed using real-time PCR.

\section{Results}

the findings of the present study reveal that there was no significant difference between of solvent recipients and the intact group in the memory retention test, the number of healthy hippocampal pyramidal neurons, and the expression of the GABAA gene. The treated groups with various doses of hydroalcoholic extract of tarragon and coumarin showed decreased in the memory retention test and the number of healthy pyramidals neurons as well as a significant increase in GABAA- a5 and GABAA- $a 2$ genes expression compared to the group receiving solvent.

\section{Conclusion}

Tarragon hydroalcoholic extract and coumarin affects memory impairment through increasing the GABAA- $a 5$ and GABAA- $a 2$ genes expression and decreasing the number of healthy hippocampal neurons.

\section{Introduction}

Learning is the behaviour changes due to gaining experience, and memory is the keeping of such information. One of the most significant performing levels of the central nervous system is learning and memory. Hippocampus is of the main brain structures involved in learning and memory (1). 
Previous studies have shown the high concentrations of GABAA receptors in the hippocampus which indicates the fact that activating GABAA receptors can control the process of learning and memory (2). Gamma-Aminobutyric Acid (GABA) is the brain's major inhibitory neurotransmitter. GABA attaching to the GABAA receptors opens the chlorine channel and causes hyperpolarization (3). Approximately $80 \%$ of all GABAA receptors contain an attaching place of benzodiazepines located in between the related subunit of $\gamma 2$ and subunit of $a(a 2, a 5)$ (4).

Tarragon (Artemisia dracunculus L.) is a perennial herbaceous plant of the Asteraceae family (5). Tarragon aerial parts include a broad array of phytochemicals such as monoterpenoids, suzocriproids, phenols, polyethylenes, alkaloids, coumarins and flavonoids (6). Tarragon flavonoids contain quercetin and eriodictyol (7). Researches carried out on Tarrogon have revealed that this plant contains bioactive compounds such as a-pinene $₫$ coumarin, trans-anethole, methyl eugenol and $y$-terpinene (7). There are some reports indicating the effect of flavonoids on the benzodiazepine position of the GABA receptor, which ultimately leads to the increasing of GABA activities (8). GABAA (a) subunits are the dominant subunits in the central nervous system and are considered essential in attaching to benzodiazepines as well as in memory (9). Studies showed that the two subunits of $a 2$ and $a 5$ are playing a more important role in memory (10). Some phenolic substances in tarragon hydroalcoholic extract such as coumarin produce anticonvulsant, anti-anxiety, and tranquillizing effects through binding to the GABAA receptors (11). Coumarin is a combination of various physiologic features such as anticoagulant, antimicrobial, antioxidant and complexes carrying the features of anti-cancer that has been taken into consideration by many chemists and pharmacists.

Coumarin is effective in decreasing seizures by binding to the benzodiazepin GABAA receptors (11). Muke and colleagues had carried out research in 2018 that showed the tranquillity and anti-anxiety effects of Coumarin probably through affecting GABAA receptors (12). Researches have done on the tarragon hydroalcoholic extract and coumarin as an effective substance with anti-pain, anti-anxiety and anticonvulsant features by behavioural methods. No research or study has been published on such substance regarding learning and memory using molecular methods. Thus, due to the importance of molecular and tissue methods on retentioning memory and through benefiting from the modern method, the present study is going to molecularly express the effects of tarragon hydroalcoholic extract and coumarin on learning and memory in the hippocampus. The present study is effect of the hydroalcoholic extract of tarragon and coumarin on memory retention, GABAA receptor gene expression and the number of healthy hippocampal pyramidal neurons in the hippocampus of male rats.

\section{Methodology}

56 male rats weighing 220 to $230 \mathrm{gr}$ were procured from the Pasteur Institute of Iran for the purpose of the present study. They were kept in standard temperature condition $\left(23 \pm 2^{\circ} \mathrm{C}\right)$ with a relative humidity of 40-45 per cent and lib access to pellets and freshwater (13). The rats were randomized into 7 groups (n $=8$ ); these groups included the intact group, the control + group receiving $0 / 5 \mathrm{cc}$ solvent, the group receiving tarragon hydroalcoholic extract with doses of 25,50 and $100 \mathrm{mg} / \mathrm{kg}$ and coumarin with doses 
of 3 and $5 \mathrm{mg} / \mathrm{kg}$. The treatment was administrated intraperitoneally once a day for 15 days (14). Tarragon was purchased from an agricultural farm in Qom that grew vegetables. Then, tarragon was matched with a sample plant preserved in the Faculty of Pharmacy of Shahid Beheshti University of Medical Sciences No. 861 (voucher specimen). The hydroalcoholic extract was provided using dried tarragon, 70\% alcohol and Soxhlet apparatus (8). Violet crystal and coumarin were obtained from Sigma Aldrich. Paraformaldehyde, gelatin, chloroform, xylazine, alcohol $96 \%$, absolute alcohol, xylene, formamide, distilled water, and DMSO were purchased from the Merck Company in Germany. Accuprep Genomic DNA extraction kit (Cat No: K-3032) and AccuPower ${ }^{\circledR} 2 X$ Greenstar qPCR Master Mix were procured from BIONEER Company. The present research protocol was approved by the Ethics Committee of the University (ethic code: IR.IAU.SRB.REC.1397.127) based on the International Laboratory Animals' Regulations.

A shuttle box contains two light and dark chambers $(30 \times 20 \times 30 \mathrm{~cm})$ and a guillotine lid $(9 \times 7 \mathrm{~cm})$ was used to measure the memory retention. The bottoms of both chambers were made of stainless steel ( $2.5 \mathrm{~mm}$ diameter) and were connected to a stimulator. The animal was put in the light side of the box for preliminary training, then after 5 seconds, the guillotine lid opened. The time required for the rat to enter the dark box was recorded. Then, it was released. This procedure was repeated 30 minutes later, yet, this time the rat was exposed to foot shock with the frequency of $50 \mathrm{~Hz}$ and voltage of $0.5-0.6 \mathrm{~mA}$ for 9 seconds just after entering the dark side $f$ the box, then after 5 seconds the rat was taken out of the device. The rat was located on the light side of the box 24 hours after training for the retention test. 24 hours after training, the rat was located on the light chamber of the box for taking the test of retention. 30 seconds later, the guillotine lid opened and the duration for entering the dark chamber of the box was recorded as the memory retention time. The whole test was taken in 600 seconds (15).

After the memory retention test using shuttle box, in order to test histology, the rats were immediately anaesthetized with chloroform to remove their brain. In each group, 4 brains were used for histological study and the other 4 were allocated for molecular study. The brains were fixed in formalin solution (10\%) and then dehydrated and moulded. 10 slides with serial cuts of 5-7 um were provided and stained with Nissl. Then, 5 sections from brain tissue of different groups were selected randomly and studied microscopically. OLYMPUS, AX70 microscope was used for cell counting and the sample images were recorded at 40X magnification. Cells were counted using Olysia bio report software. Considering the Paxinos atlas, pyramidal neurons in 3.3-3.6 sections (relative to Bregma) were selected (16).

To perform RT-PCR, the hippocampal region was firstly removed and then, immediately frozen in liquid nitrogen. Hippocampal samples were refrigerated at $-84^{\circ} \mathrm{C}$ and stored till RNA was extracted. In order to determine the expression of a2 and a5 genes in hippocampal GABAA receptors, the selected tissue was firstly homogenized and then the whole RNA of the tissue was extracted using + RNX extraction solution and chloroform- alcohol protocol. The RNA concentration test was conducted to determine the acceptable ratio of purity. Concentration was measured by a spectrophotometric method using a nanodrop device (Nanolytik The company, Germany), followed by cDNA making. 
Polymerase chain reaction (PCR) was used to amplify the CDNA of the above genes. The PCR process was expressed by AceQ ${ }^{T}$ RT_PCR SYBR Green Master using Taq polymerase enzyme and specific primers for GABAA-a2 (5'-GAACAGAGAATCGGTGCCAGCAAGA-3'(F区 (5'-

TGCAAATTCAATTAGGGCAGAGAACACAA-3')R gene, GABAA-a5 (5'-

TGCTATGCATTTGTCTTCTCTGCTCTGATT-3')F, (5'- GATTAGACCCGTTACCATCGAGAT-3')R gene, $\beta$-Actin (5'-CCCAGCCATGTACGTAGCCA3')F $\otimes\left(5^{\prime}\right.$-CGTCTCCGGAGTCCATCAC-3)R gene. The condition in a laboratory was separately optimized. Then, the condition was assessed in terms of primer binding temperature, number of cycles, and PCR rate using PCR program; and afterwards, it was assessed by using Stepone software. The thermal cycle features are as follows: 15 seconds at $95^{\circ} \mathrm{C}, 60$ seconds at $60^{\circ} \mathrm{C}$ for 40 cycles. The mean $\mathrm{Ct}$ of reference and target genes in each sample was calculated. The difference between the threshold cycle of target and reference genes in the control sample was calculated as $\Delta \mathrm{Ct}$ and the difference between them was expressed as $\triangle \triangle \mathrm{Ct}$ (17).

\section{Statistical Analysis}

All data are expressed as Mean \pm SEM. The analysis of memory retention and histology tests were conducted for statistical analysis, using One-way, analysis of variance (ANOVA). In all calculations, $\mathrm{P}<$ 0.05 was considered as a significant difference. Gene expression data were calculated and analysed by $\triangle \triangle \mathrm{Ct}$. A level difference of greater than 1 was considered as the level of significance.

\section{Results}

The group receiving solvent (control+) showed no significant difference in memory retention compared to the intact group. The groups receiving tarragon hydroalcoholic extract with doses of 50 and $100 \mathrm{mg} / \mathrm{kg}$ and coumarin with a dose of $3 \mathrm{mg} / \mathrm{kg}$ showed a significant reduction in memory retention in comparison with the control + group. (Fig. 1) The control + group reflected no significant differences in the number of hippocampus healthy neurons compared to the intact group. Those groups that received tarragon hydroalcoholic extract with doses of 50 and $100 \mathrm{mg} / \mathrm{kg}$, as well as coumarin with a dose of $3,5 \mathrm{mg} / \mathrm{kg}$, showed a significant reduction in the number of hippocampus healthy neurons compared to the control + group. (Fig. 2) and (Fig. 3). The control + group was not show significant difference in GABAA-a5 and GABAA-a2 expression compared to the control + group. The group that received tarragon hydroalcoholic extract with a dose of $25 \mathrm{mg} / \mathrm{kg}$ reflected a significant increase in GABAA-a2 gene expression compared to the control + group. (Fig. 4) Those groups that received tarragon hydroalcoholic extract with doses of 50 and $100 \mathrm{mg} / \mathrm{kg}$ showed a significant increase in GABAA-a5 gene expression compared to the control + group. (Fig. 5)

The graphs show the mean and standard deviation (Mean \pm SEM). Using variance analysis, data was one-sided and afterwards, the Toki test was analysed.

$\mathrm{n}=8,\left(\mathrm{p}<0 / 01^{\star *}\right),\left(\mathrm{p}<0 / 001^{\star \star *}\right)$ 
The histology research results indicated that the group received tarragon hydroalcoholic extract with doses of 50 and $100 \mathrm{mg} / \mathrm{kg}$ and coumarin with a dose of $3,5 \mathrm{mg} / \mathrm{kg}$ showed a meaningful decrease in the number of hippocampus healthy neurons compared to the control + group (Fig. 2) and (Fig. 3).

The graphs show the mean \pm standard deviation (Mean \pm SEM). Using variance analysis, data was onesided and afterwards, the Toki test was analysed.

$n=8,\left(p<0 / 1^{*}\right),\left(p<0 / 001^{\star * *}\right)$

The results of gene expression revealed that the group received tarragon hydroalcoholic extract with a dose of $25 \mathrm{mg} / \mathrm{kg}$ showed significantly increase in GABAA-a2 gene expression compared with the control + group. (Fig. 4)

The graphs show the mean and standard deviation (Mean \pm SEM). The level difference $\triangle \triangle \mathrm{Ct}$ was considered more than one level. $n=4$

The results of the gene expression study revealed that the group that received tarragon hydroalcoholic expression with doses of 50 and $100 \mathrm{mg} / \mathrm{kg}$ showed a significant increase in GABAA-a5 compared to the control + group. (Fig. 5)

The graphs showed the mean and standard deviation (Mean \pm SEM). The level difference $\triangle \triangle$ Ct was considered more than one level. $n=4$

\section{Discussion}

Memory is an important cognitive function without which life is not possible. Information is saved through harmonic neural networks in the brain (18). Hippocampus composition plays an important role in the calculation and saving of spatial information. The pyramidal cells of the hippocampus CA1 region are too sensitive and among the first neurons that would be destroyed in pathologic conditions and some brain degenerative diseases (19). There are dominant GABAA subunits receptors of a2 and a5 in the hippocampus that exists in whole regions of CA1 and CA3 (20). GABAA- $\alpha 2$ and GABAA-a5 receptors are high-affinity binding sites for benzodiazepines (4). These two subunits are crucial in learning and memory (21).

The suttle box of the behavioural test has been conducted for the present research to investigate learning and memory, and the results revealed that the group that received solvent showed no significant differences regarding STL amount compared to the intact group. So, the extracting solvent DMSO had no effect on the process of learning and memory in male rats. Meanwhile, the STL amount in the group that received tarragon hydroalcoholic extract with doses of 50 and $100 \mathrm{mg} / \mathrm{kg}$ and coumarin with a dose of 3 $\mathrm{mg} / \mathrm{kg}$ significantly decreased compared to the control+ group. Probably such decrease was due to direct or indirect impact on GABAA receptor which is aligned with the previous studies and researches. 
Ding et al. (2014) introduced methyl eugenol as a new agonist of ionotropic GABA receptors. Methyl eugenol has a strong inhibitory activity against nerve stimulation in hippocampal neurons. Methyl eugenol inhibits voltage-gated sodium channels, voltage-gated potassium channels and voltage-gated calcium channels (22). Intraperitoneal injection of methyl eugenol mitigates anxiety behaviours in rats, which is likely to be accompanied by the activation of GABAA receptors. Thus, compounds of tarragon such as estragole, methyl eugenol and coumarin represent a new agonist of GABAA receptors (23).

Kavvadias et al. indicated in a research conducted in 2000 that the tarragon hydroalcoholic extract contains benzodiazepines such as temazepam and lorazepam (100-200 ng/g) (24). Through binding to the GABAA receptors, benzodiazepines produce anticonvulsant effects. Such compounds as the GABAA agonist receptors increases the frequency of opening chlorine channel related to the receptors (25). Moreover, the injection of quercetin to the rats exposed to chemical kindling increases oxidative stress and produces dose-dependent anticonvulsant effects (26). Naringenin passes through the blood-brain barrier and affects the central nervous system via the GABAA receptors (27). The injecting alpha-Pinene to the rats and recording of electroencephalographic curves of the brain also illustrates the binding of the benzodiazepine site of GABAA receptors to alpha-Pinene, which is used as insomnia medication (28). Terpinene induces effects similar to those of pentobarbital and diazepam including strong sedative and anticonvulsant effects (29). Ahmad Tarmizi et al (2014) showed in research that trans-anethole through binding to the GABAA receptor increase its activity and could be used as an anti-epileptic drug (30). Also coumarin injection to the rats produced sedative and anti-epileptic effects that control the brain's neurons through increasing GABAA release. Coumarin attached to the benzodiazepine site of GABAA receptor in three points and increases the activities of this receptor as an anti-epileptic drug (9).

Jarogniew et al. (2010) used electronic kindling to create convulsion and through injecting intraperitoneal coumarin to rats, they found that convulsion threshold has extremely decreased; and probably such result was due to attachment of coumarin to the GABAA receptor and the increase of its activity (31).

The comparison of the mentioned results with the present research indicates that probably the tarragon hydroalcoholic extract having different substances attached to the benzodiazepine sites in GABAA receptors such as coumarin increases the activities of this receptor and by opening the chloride channel of such receptor fortifies hyperpolarization and finally intensifies the memory disorder in male rats.

In the present study, a histology test has been performed using Nissle colouring for measuring the density of the pyramidal healthy neurons cells of the hippocampus. The results show that the decrease of pyramidal healthy cells in the treated group with 50 and $100 \mathrm{mg} / \mathrm{kg}$ doses of tarragon hydroalcoholic extract, 3 and $5 \mathrm{mg} / \mathrm{kg}$ coumarin indicated the destruction of hippocampus pyramidal cells compared to the control+ group probably through substances in the tarragon hydroalcoholic extract which confirms the results of Guo et al. researches conducted in 2020. The findings of the research showed that the intraventricular injection of methyl eugenol to rats ended in the increase of tension in rats. Meanwhile, methyl eugenol extremely caused hippocampus functional disorder at behavioural, cellular and molecular levels and this indicated potential dangers of methyl eugenol to the central nervous system (32). 
Moreover, Pawel Kowalczyk et al (2020) researches showed the anti-cancer and antimicrobial effects of coumarin; yet, excessive consumption of coumarin might negatively affect the live cell and even destroy lung and liver's cells. In addition, the toxic effect of coumarin destroys the live cells including bacteria (33, 34). Thus, it seems the toxic feature of coumarin depending on its dose has affected the hippocampus pyramidal cells.

A real-time PCR test was used in the present study to express the gene. The results of the RT_PCR test indicated that GABAA-a2 and GABAA-a5 gene expression in the control+ group showed no significant difference compared to the intact group. So, the solvent had probably no effect on the two genes expression. Yet, the GABAA-a5 gene expression in the group treated with 50 and $100 \mathrm{mg} / \mathrm{kg}$ dose of tarragon hydroalcoholic extract significantly increased in comparison to the control+ group. The two subunits of a2 and a5 of GABAA receptors play important roles in memory (35). GABAA receptors have also binding sites for componds of benzodiazepine, barbital and steroids; these receptors at the presence of GABA and in some cases directly, induce GABAA and activate the receptors' channel (36). Since the high density of GABAA receptors in the hippocampus indicate that activating the GABAA receptors can control the process of learning and memory (37), it is probable that the memory disorder reported in this group is due to the increase of GABAA-a5 gene expression, the increase of GABAA inhibitory synapses, the increase of time duration of such synapses and finally because of the more sensitivity of such receptors to the GABA. The present research result shows the overlapping of histology and RT_PCR tests, which is consistent with previous findings.

Zhao et al. found in research that injecting a low dose of isoflurane (anaesthesia substance) can decrease the GABAA-a5 gene mRNA expression in hippocampus nerve cells in old ages, yet it is increased in young animals. These findings showed that L-655708 injection (agonist GABAA-a5) inhibits spatial learning, memory disorder and spatial memory due to isoflorane in Wistar old rats (38).

Magnin et al. found in research that inhibiting GABAA-a5 in rats controlled can also improve spatial learning compared to the rats having the inactive vasoactive intestinal peptide in the CA1 region (39).

Etherington et al. carried out a study that $\mathrm{S} 44819$ is a tricyclic peptide that can act as the chosen agonist of GABAA-a5 Receptor, thus, S44819 causes the hippocampus synopsis flexibility and increases prerecognition effectiveness. Regarding such features, S44819 might improve the recognition functions in neurological disorders and make it easier to recover after a stroke (40).

Vinnakota et al. (2020) conducted research indicated that a5IA[1] injection, a reversed agonist of GABAAa5 receptors to Alzheimer induced rats could prevent cell destruction due to $\left(A \beta_{1-}{ }_{42}\right)$ in a laboratory condition that might hold neuroprotective features (41).

Magnin et al. (2018) considered a relation between memory disorder and the increase of GABAA-a5 receptor gene in hippocampus CA1 pyramidal cells (40). Moreover, GABAA- $a 2$ gene expression in the group treated with $25 \mathrm{mg} / \mathrm{kg}$ tarragon hydroalcoholic extract showed a significant increase compared to the control+ group. Since the high density of GABA receptors in the hippocampus indicates that 
activating GABA receptors controls the process of learning and memory, (2) it is probable that memory disorder in this group was due to the increase of GABAA- $a 2$ gene expression, the increase of GABA inhibitory synopsis, the increase of the synopsis time duration and the more the sensitivity of such receptors to GABA. These findings are consistent with the previous results.

Julian I. Hofmann et al. showed in research that prescribing diazepam to wild rats with GABAA-a2 mutant gene resulted in changes in the automatic electronic activity patterns in brain cortex through using benzodiazepine so that the low-frequency increase of produced $y$ by diazepam might reflect the increased inside cortex harmony. By increasing the high-frequency band, diazepam decreases the frequency power through GABAA-a2 receptors (42).

Toshihiro Nomura et al. conducted research and found that enhancing subunits a2 holding GABAA receptors in Dravet (severe Myoclonic epilepsy in infants) syndrome model can protect rats against convulsions (43).

\section{Footnote:}

[1] 3-(5-Methylisoxazol-3-yl)-6-[(1-methyl-1,2,3-triazol-4-yl)methyloxy]-1,2,4-triazolo[3-a]phthalazine

\section{Conclusion}

Having different substances attached to the benzodiazepine sites in GABAA receptors, tarragon hydroalcoholic extracts might increase the activities of GABAA receptors as well as hyperpolarization through increasing GABAA-a5 and GABAA-a2 gene expression, and coumarin causes memory disorder in the hippocampus of male rats through decreasing the number of healthy pyramidal neurons. It should be noted that there is a need for extra studies.

\section{References}

1. Stephens DW, Dunlap AS. Foraging (2017) Learning and Memory: A Comprehensive Reference. Elsevier Inc., pp 237-253. https://doi.org/10.1016/B978-0-12-809324-5.21014-6

2. Helm K, Haberman R, Dean S, Hoyt E, Melcher T, Lund P et al (2005) GABAB receptor antagonist SGS742 improves spatial memory and reduces protein binding to the cAMP response element (CRE) in the hippocampus. Neuropharmacology 48(7):956-964.

https://doi.org/10.1016/j.neuropharm.2005.01.019

3. leite JF cM. structure of ligand-gated ion channels critical assessment of biochemical data supports novel topology. mol cell neurosci. 2001;17(5):777-9 https://doi.org/10.1006/mcne.2001.0984

4. Nelson TS, Holstein SE, Baird J-P, Pittman DW (2019) Selective stimulation of central GABAAa2, 3, 5 receptors increases intake and motivation to consume sucrose solution in rats. Neuroscience 409:111-119. https://doi.org/10.1016/j.neuroscience.2019.04.040 
5. Arabhosseini A, Huisman W, van Boxtel A, Muller (2007) J Long term effects of drying conditions on the essential oil and color of tarragon leaves during storage. J Food Eng 79(2):561-566. https://doi.org/10.1016/j.jfoodeng.2006.02.014

6. Chauhan R, Kitchlu S, Ram G, Kaul M, Tava A (2010) Chemical composition of capillene chemotype of Artemisia dracunculus L. from North-West Himalaya, India. Ind Crops Prod 31(3):546-549. https://doi.org/10.1016/j.indcrop.2010.02.005

7. Bhutia TD, Valant-Vetschera KM. Chemodiversity of Artemisia dracunculus L. from Kyrgyzstan: Isocoumarins, coumarins, and flavonoids from aerial parts. Natural Product Communications. 2008;3(8):1934578X0800300811. https://doi.org/10.1177\%2F1934578X0800300811

8. Kahnberg P, Lager E, Rosenberg C, Schougaard J, Camet L, Sterner O et al (2002) Refinement and evaluation of a pharmacophore model for flavone derivatives binding to the benzodiazepine site of the GABAA receptor. J Med Chem 45(19):4188-4201. https://doi.org/10.1021/jm020839k

9. Mohammadi-Khanaposhtani M, Ahangar N, Sobhani S, Masihi PH, Shakiba A, Saeedi M et al (2019) Design, synthesis, in vivo, and in silico evaluation of new coumarin-1, 2, 4-oxadiazole hybrids as anticonvulsant agents. Bioorganic chemistry 89:102989. https://doi.org/10.1016/j.bioorg.2019.102989

10. Savić MM, Milinković MM, Rallapalli S, Clayton Sr T, Joksimović S, Van Linn M et al (2009) The differential role of a1-and a5-containing GABAA receptors in mediating diazepam effects on spontaneous locomotor activity and water-maze learning and memory in rats. Int $\mathrm{J}$ Neuropsychopharmacol 12(9):1179-1193. https://doi.org/10.1017/S1461145709000108

11. Skalicka-Woźniaka KOE, Geoffrey A. Cordellc, d, Nabavie M, Budzyńskaf B. Implication of coumarins towards central nervous system disorders. Pharmacological Research. 2016;103:188-203 https://doi.org/10.1016/j.phrs.2015.11.023

12. Muke SA, Peshattivar VV, Kaikini AA, Bagle SR, Dighe V, Sathaye S. Neuroprotective effect of coumarin nasal formulation: kindling model assessment of epilepsy. Front Pharmacol. 2018;9:992. https://www.frontiersin.org/articles/10.3389/fphar.2018.00992/full

13. motlagh nA, Rouhani AH, Zarindast Mr, Nsehi M (2014) Evaluation of GABAergic system (GABAb receptor) of CA1 region of hippocampus on spatial and non-spatial memory in male NMRI mice. Animal Biology 6(4):51-60. https://www.sid.ir/fa/VEWSSID/J_pdf/24913930406.pdf

14. Cheriyan Sr BV, Kadhirvelu Sr P, Nadipelly J Jr, Shanmugasundaram J, Sayeli Sr V, Subramanian Sr V (2017) Anti-nociceptive effect of 7-methoxy coumarin from Eupatorium Triplinerve vahl (Asteraceae). Pharmacognosy magazine 13(49):81. https://www.ncbi.nlm.nih.gov/pmc/articles/PMC5307919/

15. Alipour M, Adineh F, Mosatafavi H, Aminabadi A, Monirinasab H, Jafari MR (2015) Effect of chronic intraperitoneal aminoguanidine on memory and expression of Bcl-2 family genes in diabetic rats. Can J Physiol Pharmacol 94(6):669-675. https://doi.org/10.1139/cjpp-2015-0357

16. Schultz SK (2001) Principles of neural science. Am J Psychiatry 158(4):662. https://doi.org/10.1176/appi.ajp.158.4.662 
17. Annovazzi L, Mellai M, Caldera V, Valente G, Schiffer D (2011) SOX2 expression and amplification in gliomas and glioma cell lines. Cancer Genomics-Proteomics 8(3):139-147. http://cgp.iiarjournals.org/content/8/3/139.full.pdf

18. Morris RG, Moser E, Gernot MS, Johan, Day M, O'Carroll C (2003) Elements of a neurobiological theory of the hippocampus: the role of activity-dependent synaptic plasticity in memory. Philosophical Transactions of the Royal Society of London Series B: Biological Sciences 358(1432):773-786. https://www.ncbi.nlm.nih.gov/pmc/articles/PMC1693159/pdf/12744273.pdf

19. Whittle S, Yap MB, Sheeber L, Dudgeon P, Y?? cel M, Pantelis $C$ et al (2011) Hippocampal volume and sensitivity to maternal aggressive behavior: A prospective study of adolescent depressive symptoms. Dev Psychopathol 23(1):115. DOI:10.1017/S095457941000068

20. Sperk G, Schwarzer C, Tsunashima K, Fuchs K, Sieghart W (1997) GABAA receptor subunits in the rat hippocampus I: immunocytochemical distribution of 13 subunits. Neuroscience 80(4):987-1000. https://doi.org/10.1016/S0306-4522(97)00146-2

21. Myers JF, Comley RA, Gunn RN (2017) Quantification of [11C] Ro15-4513 GABAAa5 specific binding and regional selectivity in humans. Journal of Cerebral Blood Flow Metabolism 37(6):2137. https://doi.org/10.1177\%2F0271678X16661339. -48(2,3)

22. Ding J, Huang C, Peng Z, Xie Y, Deng S, Nie Y-Z et al (2014) Electrophysiological characterization of methyleugenol: A novel agonist of GABA (A) receptors. ACS Chem Neurosci 5(9):803-811. https://doi.org/10.1021/cn500022e

23. Liu Y-M, Fan H-R, Deng S, Zhu T, Yan Y, Ge W-H et al (2019) Methyleugenol potentiates central amygdala GABAergic inhibition and reduces anxiety. J Pharmacol Exp Ther 368(1):1-10. https://doi.org/10.1124/jpet.118.250779

24. Abou-Mandour DK, F A (2000) C, H B, P S,P R, et al. Identification of Benzodiazepines in Artemisia dracunculus and Solanum tuberosum rationalizing Their Endogenous Formation in Plant Tissue. Biochemical Biophysical Research Communications; 296:290-295. https://doi.org/10.1006/bbrc.2000.2283

25. Farajnia S, Janahmadi M, Vatanparast J, Abbasipour H (2011) The Electrophysiological Consequences of Artemisia dracunculus L.(Tarragon) Extract on Pentylenetetrazol-Induced Epileptiform Activity in Snail Neurons. Journal of Medicinal Aromatic Plants Research 12(48):803811. https://www.sid.ir/en/Journal/ViewPaper.aspx?ID=189217

26. Nassiri-AsI M, Moghbelinejad S, Abbasi E, Yonesi F, Haghighi M-R, Lotfizadeh M et al (2013) Effects of quercetin on oxidative stress and memory retrieval in kindled rats. Epilepsy Behav 28(2):151-155. https://doi.org/10.1016/j.yebeh.2013.04.019

27. Jäger AK, Krydsfeldt K, Rasmussen HB (2009) Bioassay-guided isolation of apigenin with GABAbenzodiazepine activity from Tanacetum parthenium. Phytotherapy research 23(11):1642-1644. https://doi.org/10.1002/ptr.2816

28. Yang H, Woo J, Pae AN, Um MY, Cho N-C, Park KD et al (2016) a-Pinene, a major constituent of pine tree oils, enhances non-rapid eye movement sleep in mice through GABAA-benzodiazepine receptors. 
Mol Pharmacol 90(5):530-539. DOl:https://doi.org/10.1124/mol.116.105080

29. Kobayashi Y, Takemoto H, Fu Z, Shimizu E, Kinjo Y. Enhancement of Pentobarbital-induced Sleep by the Vaporized Essential Oil of Citrus keraji var. kabuchii and its Characteristic Component, $\mathrm{Y}^{-}$ Terpinene. Natural Product Communications. 2016;11(8):1934578X1601100836 https://doi.org/10.1177\%2F1934578X1601100836

30. Has ATC, Islam MR, Baburin I (2014) The inhibitory activity of nutmeg essential oil on GABAA? 1? 2? 2s receptors. Biomed Res 25(4):0976-1683. https://www.biomedres.info/biomedical-research/theinhibitory-activity-of-nutmeg-essential-oil-on-gabaa-122s-receptors.html (Electronic)

31. Jarogniew J. Łuszczki MA-M (2010) Michał Gleńsk \& Krystyna Skalicka-Woźniak Anticonvulsant effects of four linear furanocoumarins, bergapten, imperatorin, oxypeucedanin, and xanthotoxin, in the mouse maximal electroshock-induced seizure model: a comparative study. Pharmacological Reports 62:36-1231. https://doi.org/10.1016/S1734-1140(10)70387-X

32. Guo K-F, Dai M, Liu Y-M, Zhang J-C, Chen Y-M, Ye H et al (2020) Acute Administration of Methyleugenol Impairs Hippocampus-Dependent Contextual Fear Memory and Increases Anxiety-like Behavior in Mice. Food Chem 68(28):7490-7497. https://doi.org/10.1021/acs.jafc.0c01863

33. Kowalczyk P, Madej A, Paprocki D, Szymczak M, Ostaszewski R. Coumarin Derivatives as New Toxic Compounds to Selected K12, R1-R4 E. coli Strains. Materials - Open Access Journal 2020;13(2499) https://doi.org/10.3390/ma13112499

34. Lonc`ar M, Jakovljevic' M, Šubaric' D, Služek MP, Cindric' VB I, et al. Coumarins in Food and Methods of Their Determination. Foods - Open Access Journal 2020;9(645). https://doi.org/10.3390/foods9050645

35. Savić MM, Milinković MM, Rallapalli S, Clayton Sr T, Joksimović S, Van Linn M et al (2009) The differential role of a1-and a5-containing GABAA receptors in mediating diazepam effects on spontaneous locomotor activity and water-maze learning and memory in rats. Int J Neuropsychopharmacol 12(9):1179-1193. https://doi.org/10.1017/S1461145709000108

36. Nestler EJ, Hyman SE, Malenka RC (2001) Molecular neuropharmacology: a foundation for clinical neuroscience. McGraw-Hill Medical, pp 6-7. http://dx.doi.org/10.1136/jnnp.73.2.210-a

37. Stolt A-C, Schröder H, Neurath H, Grecksch G, Höllt V, Meyer MR et al (2014) Behavioral and neurochemical characterization of kratom (Mitragyna speciosa) extract. Psychopharmacology 231(1):13-25. https://doi.org/10.1007/s00213-013-3201-y

38. Zhao Z-F, Du L, Gao T, Bao L, Luo Y, Yin Y-Q et al. Inhibition of a5 GABAA receptors has preventive but not therapeutic effects on isoflurane-induced memory impairment in aged rats. Neural regeneration research. 2019;14(6):1029 https://dx.doi.org/10.4103\%2F1673-5374.250621

39. Magnin E, Francavilla R, Amalyan S, Gervais E, David LS, Luo X et al (2018) Input-Specific Synaptic Location and Function of the a5 GABAA Receptor Subunit in the Mouse CA1 Hippocampal Neurons. J Neurosci 39(5):788-801. DOI:10.1523/JNEUROSCI.0567-18.2018

40. Etherington L-A, Mihalik B, Pálvölgyi A, Ling I, Pallagi K, Kertész S et al (2017) Selective inhibition of extra-synaptic a5-GABAA receptors by S44819, a new therapeutic agent. Neuropharmacology 
125:353-364. https://doi.org/10.1016/j.neuropharm.2017.08.012

41. Chitra Vinnakota 1 KG, Warren Perry Tate 2, Katie Peppercorn 2, Praju Vikas Anekal 3, Henry John Waldvogel 1, Richard Lewis Maxwell Faull 1 and Andrea Kwakowsky $1,{ }^{*}$ An a5 GABAA Receptor Inverse Agonist, a5IA, Attenuates Amyloid Beta-Induced Neuronal Death in Mouse Hippocampal Cultures International Journal of Molecular Sciences 2020;21.(9). https://doi.org/10.3390/ijms21093284

42. Hofmann JI, Schwarz C, Rudolph U, Antkowiak B (2019) Effects of Diazepam on Low-Frequency and High-Frequency Electrocortical $y$-Power Mediated by a1-and a2-GABAA Receptors. Int J Mol Sci 20(14):3486. https://doi.org/10.3390/ijms20143486

43. Nomura T, Hawkins NA, Kearney JA, George AL Jr, Contractor A (2019) Potentiating a2 subunit containing perisomatic GABAA receptors protects against seizures in a mouse model of Dravet Syndrome. J Physiol 597(23):4293-4307. DOI:10.1113/JP277651

\section{Figures}

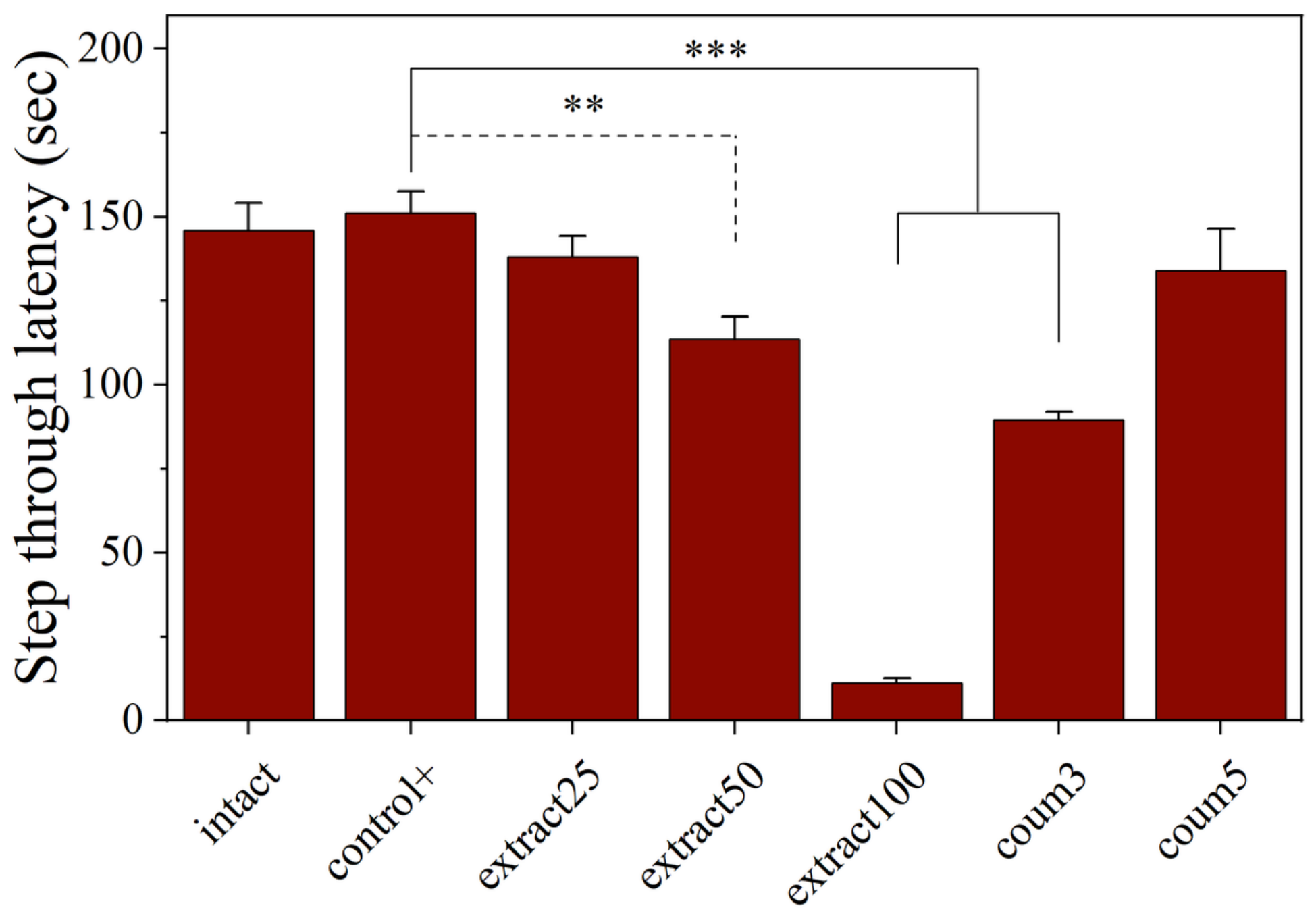

Normal rats groups 
Figure 1

the effect of tarragon hydroalcoholic extract and coumarin on the delayed entrance of the male rats to the dark chamber of the shuttle box on the test day

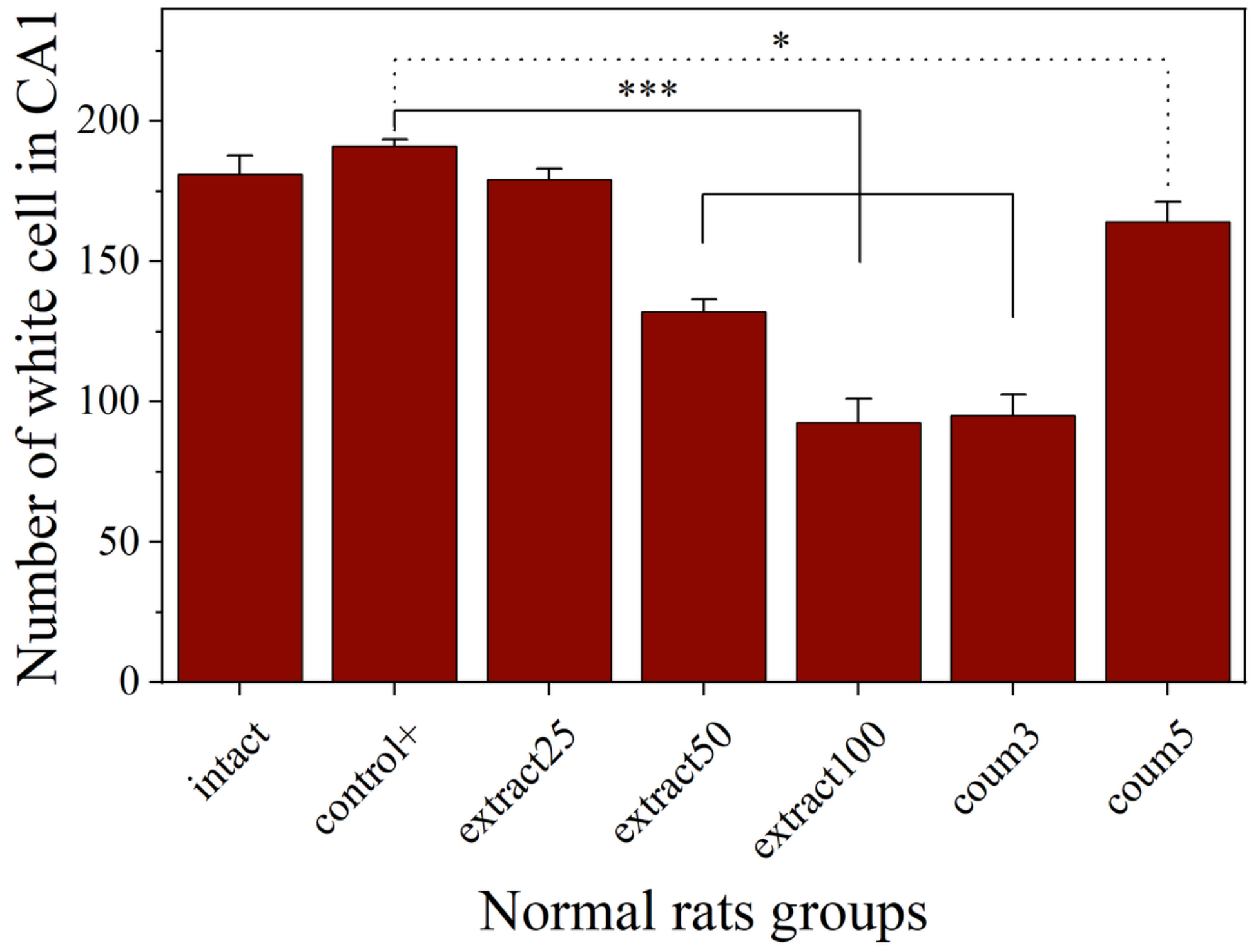

Figure 2

the effect of tarragon hydroalcoholic extract and coumarin on the number of pyramidal healthy neurons in Cornu Ammonis (CA1) region hippocampus on Male rats (quantity study of histology) 

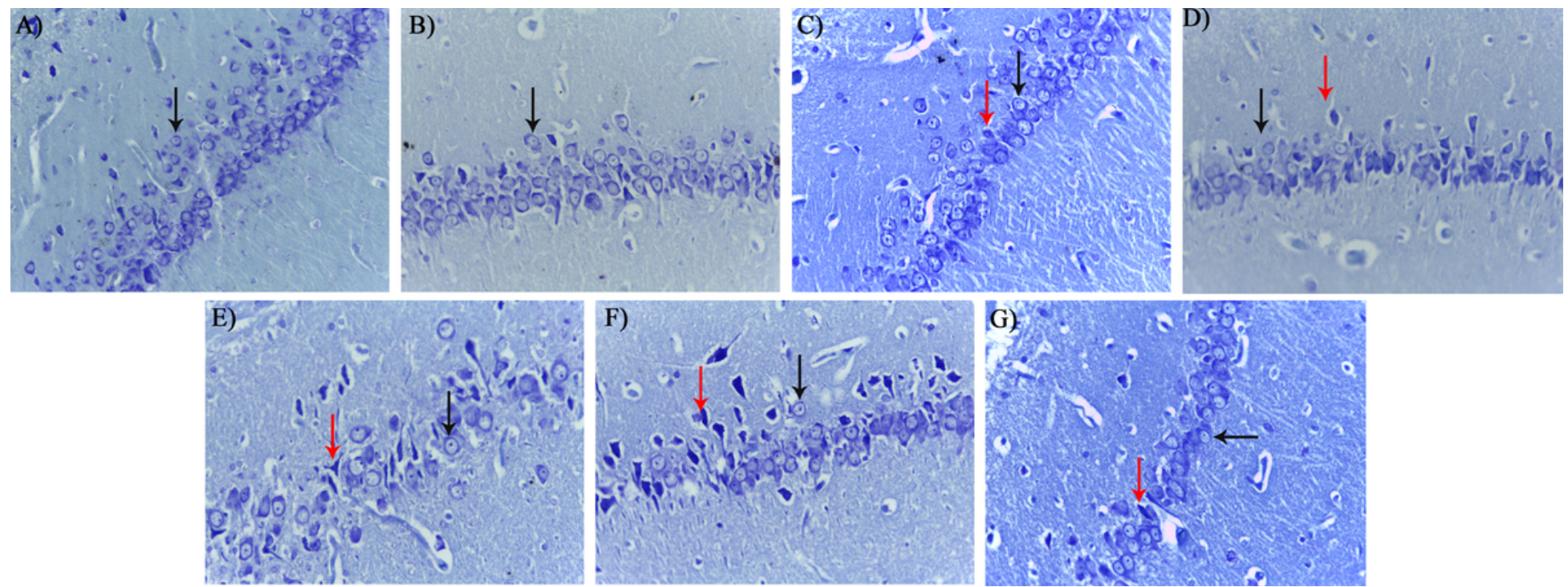

\section{Figure 3}

Histological images (quantity research) of the Nissl from the CA1 area of the hippocampus in the male rats $\mathrm{A}$ ) The tissue section of CA1 region of Hippocampus of 40X magnification in the untreated group that received no substance (intact). In this group no decline or necrosis of neurosis cells was reported. Lots of pyramidal healthy cells (White cell) can be seen with a bright core and black arrow. B) The tissue section of the CA1 region of the Hippocampus of 40X magnification in the treated group with solvent (control+); in this group, an insignificant decline or neuron cells necrosis was reported comparing to the intact group. C) The tissue section of the CA1 region of the hippocampus in the healthy group treated with a $25 \mathrm{mg} / \mathrm{kg}$ dose of tarragon hydroalcoholic extract (Extract 25); in this group, the decline or nervous cells necrosis was insignificant in comparison with the control+ group. Meanwhile, the pyramidal cells necrosis (Dark Cell) with picnose nucleus using red arrow can be observed. D) The tissue section of CA1 region of the hippocampus in the healthy group treated with $50 \mathrm{mg} / \mathrm{kg}$ dose of tarragon hydroalcoholic extract (Extract 50); in this group the decline or nervous cells necrosis was significantly observable in comparison with the control+ group. E) The tissue section of CA1 region of the hippocampus in the healthy group treated with $100 \mathrm{mg} / \mathrm{kg}$ dose of tarragon hydroalcoholic extract (Extract 100); in this group the decline or nervous cells necrosis was significantly observable in comparison with the control+ group. F) The tissue section of CA1 region of the hippocampus in the healthy group treated with $3 \mathrm{mg} / \mathrm{kg}$ dose of coumarin (coum 3); in this group the decline or nervous cells necrosis was significantly observable in comparison with the control+ group. G) The tissue section of the CA1 region of the hippocampus in the healthy group treated with a $5 \mathrm{mg} / \mathrm{kg}$ dose of coumarin (coum 5); in this group the decline or nervous cells necrosis was insignificant compared to the control+ group. 


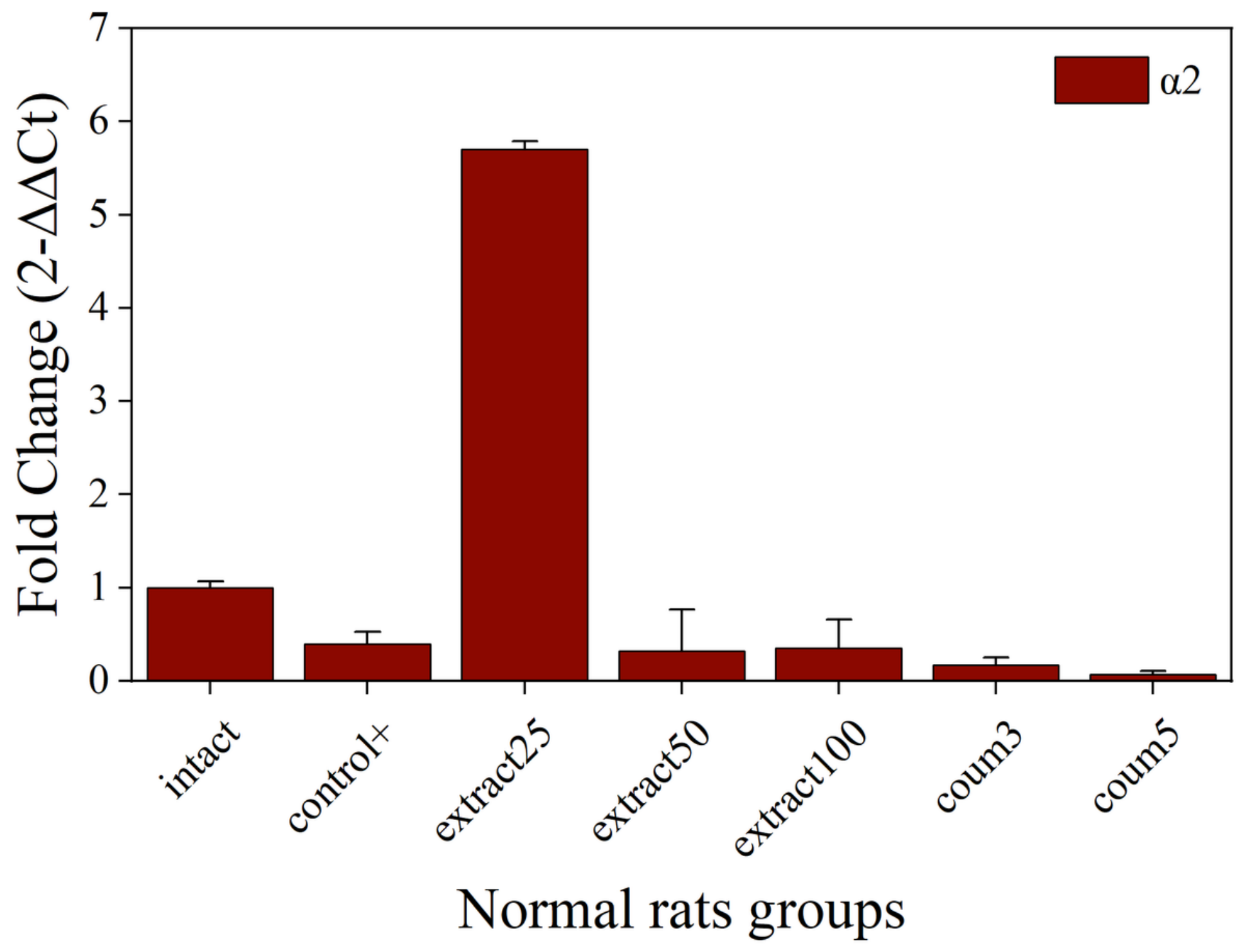

Figure 4

the relative level of mRNA GABAA-a2 gene in the hippocampus of male rats treated with tarragon hydroalcoholic extract of 25,50 and $100 \mathrm{mg} / \mathrm{kg}$ doses and coumarin with doses of 3 and $5 \mathrm{mg} / \mathrm{kg}$ compared to the control+ group 


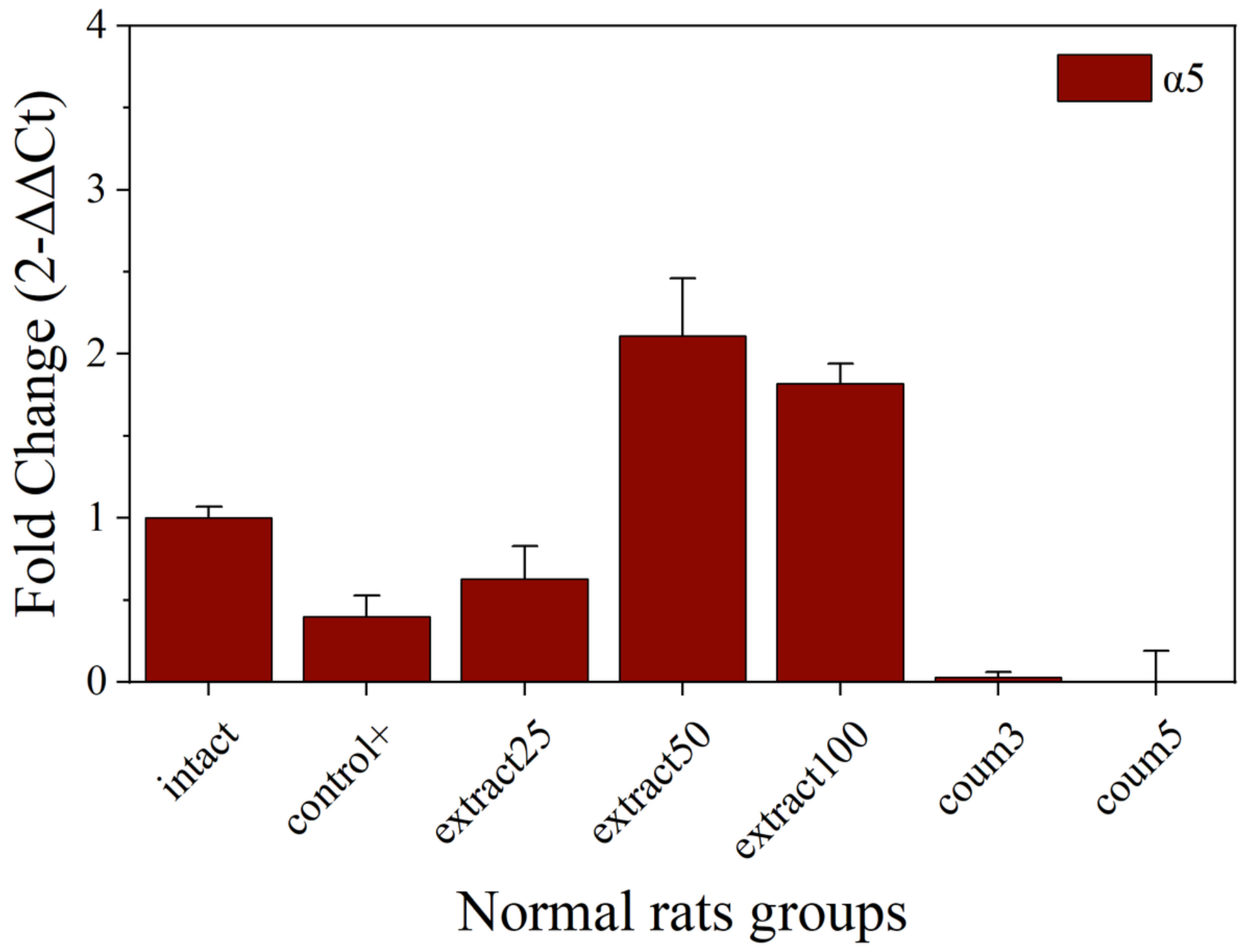

Figure 5

the relative level of mRNA GABAA-a5 in male rats hippocampus treated with tarragon hydroalcoholic extract with doses of 25,50 and $100 \mathrm{mg} / \mathrm{kg}$ and Coumarin with doses of 3 and $5 \mathrm{mg} / \mathrm{kg}$ compared with control+ group. 